\title{
Analysis of Urban Floodplain Encroachment: Strategic Approach to Flood and Floodplain Management in Kaduna Metropolis, Nigeria
}

\author{
C. Ndabula \\ Department of Geography, College of Natural \& Applied science, Kwararafa University \\ Wukari, Taraba State, Nigeria \\ Tel: 234-706-581-7224 E-mail: ndayabu_la@yahoo.com \\ G. G. Jidauna \\ Department of Geography, College of Natural \& Applied science, Kwararafa University \\ Wukari, Taraba State, Nigeria \\ Tel: 234-706-609-9392Ｅ-mail: jidauna@yahoo.com
}

K. Oyatayo

Department of Geography, Amadu Bello University, Zaria, Kaduna State, Nigeria

Tel: 234-807-745-9070Ｅ-mail: kennies624@yahoo.com

P. D. Averik

Geography Department of Geography and Environmental Management

University of Port-Harcourt, Rivers State, Nigeria

Tel: 234-807-710-5455 E-mail: dpaverik_69@yahoo.com

E. O. Iguisi

Department of Geography, Ahmadu Bello University, Zaria, Kaduna State, Nigeria

Tel: 234-803-703-7516 E-mail: ediguisi@yahoo.com

Received: August 8, 2011 Accepted: August 29, 2011 Published: March 1, 2012

doi:10.5539/jgg.v4n1p170 URL: http://dx.doi.org/10.5539/jgg.v4n1p170

\begin{abstract}
This study was aimed at monitoring, mapping and characterisation of floodplain encroachment patterns on the River Kaduna floodplain in Kaduna metropolis, Nigeria,as part of the approach to flood hazard evaluation, flood risk assessment and effective flood and floodplain management. A Topomap of 1967 was used to extract the base built-up layer, while Landsat.TM, 1987, Spot.XS, 1995, Landsat.ETM, 2001 and Quickbird, 2006 were used to generate other built-up layers, which were extracted by digitization and converted to polygon shape files and later used for overlay analysis. A Digital Elevation Map (DEM) of the area was used for delineation of floodplain boundary. ArcGIS sorfware 9.0 operational tools was highly robust and flexible for mapping and analysis of urban growth patterns and characterisation of floodplain encroachment by communities. From the results, it was observed that the highest extents and rates of encroachment are recorded by communities in the proximity of the Central Business District (CBD) such as T/Wada, Ung. Rimi, Barnawa, Doka and the industrial layouts of Kakuri and Kudenda. These areas are the centers of highest socio-economic infrastructure which implies greater flood risk and damage potential in the event of flooding. Results also showed that about $52.83 \%$ of the urban segment of the River Kaduna total floodplain area of $48.55 \mathrm{~km}^{2}$, has been encroached by built-up. As a result of this pattern of encroachment, strong institutional framework and investment towards effective floodplain management is recommended.
\end{abstract}


Keywords: Urban, Flood, Floodplain, Encroachment, Management

\section{Introduction}

Floodplain is a vital part of the river/stream ecosystem that acts as flood buffer, water filter, nursery, major center for biological life and provide fresh water for wetlands (Tadaferua, 2003). Floodplain is the part of a river morphology that is most prone to flooding in the event of over bank spill accompanying high intensity rainstorm surface-runoff, collapsed or deliberate discharge from reservoirs. Most early urbanization thrived along valleys and floodplains of major rivers (Langbein, 1978). The morphological features of floodplains which include fertile alluvial soils, flat topography and moderate gradient, make them less costly in terms of socio-economic development and thus, have encouraged encroachment (Jaenig, 2006). Floodplain encroachment has seriously increased flood risk and damage potential, especially of urban floods due to heavy socio-economic infrastructural development on these floodplains. Gilbert (1991) asserted that urban encroachment into floodplain alters the integration of surface- runoff with the main channel, reduces surface water storage and conveyance capabilities, reduces water quality of receiving waters and adjacent lands, in addition to other secondary effects such as depletion of water resources, cumulative impact on wetlands and pollution of downstream surface waters. The practice of urban encroachment on floodplains has also, exacerbated the extension of internal flooding due to reduction in floodplain's capacity to attenuate flood, thereby bringing more areas of the urban built-up under flood vulnerability (Beyer, 1974, Burton, Kate and white,1978, Jaenig, 2006). Floodplain encroachment has caused urban floodplain management to become a major concern worldwide, especially the contemporary rising trends in urban flooding. The problem is even more critical in developing cities where there is poor control over land use practices within floodplains and inadequate institutional mechanism to enforce floodplain ordinances (George, 2006).

Floodplain management is largely directed towards alleviating the damage potential of existing development which is at risk of flooding and to ensure that there is no growth in the potential for loss due to future development by taking into account the dynamics of urban encroachment on flood prone areas (Correia, 1999).

In recent times floodplain management approach recognizes the role urbanization plays in changing floodplain characteristics, interaction between mainstream and storm water, flood risk, flood hazard and the relevant planning factors.

The consequences of ineffective floodplain management are widespread and enormous, usually including socio-economic losses, ecological threats to riverine and floodplain ecosystems, adverse hydrological and geomorphological processes on floodplain and mainstream channel, spread of epidemics and loss of lives. Therefore, understanding of the nature of urban land use changes on floodplain is vital for flood and floodplain management, modeling aspects of river hydrology and hydraulics, planning infrastructure and urban extension. Accurate and updated flood plain maps can be veritable tools for safety measures such as disaster warning, evacuation and other hazards responses (Chapman and Canaan, 2001).

Some of the most critical flood problems occur in rapidly developing urban areas where values at risk are higher and damages tend to be heavier. A realistic approach to flood management in these situations require the consideration of urban growth scenarios, floodplain encroachment and the simulation of the corresponding flood conditions. Flood management cannot be dissociated from land-use management, and non-structural measures for flood control.

This study, therefore, is aimed at characterizing and analyzing urban development encroachment dynamics on floodplain in Kaduna metropolis as a strategic approach to flood and flood management, using the RS/GIS tools. This study will compliment other studies by Folorunsho (2004), Mallo (1997), and Abashiya (2006), which have dominated their focuses on surface-runoff dynamics following urban land use changes, urban flood generating structures in Kaduna metropolis.

\section{Study Area}

Kaduna metropolis is located between Lat. N1 $10^{\circ} 23^{\prime}$ and $10^{\circ} 43^{\prime} \mathrm{N}$ and Long. $7^{\circ} 17^{\prime}$ and $7^{0} 37^{\prime} \mathrm{E}$. It is characterized by the $A_{w}$ tropical continental climate according to Koppens classification (1928), with seasonal rainfall patterns which are characteristically of high intensities. Mean annual rainfall totals is about $1,185 \mathrm{~mm}$ (Sawa, 2002). Mean annual temperature is about $24.5^{\circ} \mathrm{C}$ and annual evapotranspiration almost equate annual rainfall total. River Kaduna is the major river that almost divide the metropolis into two halves.

The city is located in a tropical continental climate with distinct wet and dry seasons. The bedrock geology is predominantly metamorphic rocks of the basement complex consisting of gneisses and older granites. The soils are typical red-brown to red-yellow tropical ferruginous soils with vegetation comprising savannah grassland 
with scattered trees and woody shrubs. The population of the city has experienced rapid growth from about 169,125 in 1967 to a projected figure of $1,371,805$ in 2009 from the 2006 population census.

\section{Methodology}

The method used involved floodplain analysis carried out in three major steps as suggested by Dodson and Li (1999), as follows: data collection and preparation, extraction of floodplain boundary from Digital Elevation Model and floodplain encroachment mapping and analysis.

From the DEM, the boundaries of the floodplain were delineated by digitizing and polygonising to shape files using ArcGIS software. On the other hand urban growth was monitored by extracting built-up layers using topomap of 1967 and multi-temporal satellite data sets; Lansat.TM, 1987, Spot.XS, 1995 and Landsat.ETM, 2001 and Quickbird, 2009. These built-up vector layers together with that extracted from topomap of 1967 were composed by GIS overlay and extents of built-up were measured for the respective data sets for the periods the represented. Mapping and measurement of floodplain encroachment was achieved by superimposition of delineated floodplain boundary over the respective built-up layers. Encroachment extents by the various communities along the floodplain was analysed by overlaying the floodplain layer over already fragmented sub-centers built-up layers of 1967, 1987, 1995, 2001 and 2009 respectively, and clipped out, converted to polygons and spatial measurement of area performed using ArcGIS tool.

\section{Results Analysis and Discussions}

Kaduna metropolis has experienced significant spatial growth in built-up extents, from $21.10 \mathrm{~km}^{2}$ in 1967 to $181.01 \mathrm{~km}^{2}$ in 2009 as represented in the map in Figure 2a and summarized in Table 1. This growth has been accompanied with simultaneous encroachment on the River Kaduna floodplain, in an increasing trend from 2.02 $\mathrm{km}^{2}(4.16 \%)$ in 1967 to $25.65 \mathrm{~km}^{2}(52.83 \%)$ in 2006 . This showed that more than half of the floodplain of the metropolis segment of River Kaduna has been encroached upon by built-up. The fastest encroachment was observed in the 1980s which corresponds with the rapid industrialization and urbanization in Kaduna metropolis and has proceeded at a gradual rate since then to date.

Floodplain encroachment rate was observed by communities for the periods of 1967, 1987, 1995, 2001 and 2009 respectively and results is shown in Table 2. The general pattern revealed Doka (the central Business District) showing the largest encroachment amongst other earliest communities including Tudun wada, Ung Rimi, Kakuri and Barnawa that recorded encroachment since the 1960s. These communities have however, shown great disparities in the spatio-temporal patterns of encroachment since 1967 to 2009. The highest extents and rates of communities encroachment were observed in the 1980s and have since then proceeded at gradual rate to 2009 . Tudun wada has the largest change in extent of encroachment of $3.43 \mathrm{~km}^{2}$, followed by Ung Muazu $2.91 \mathrm{~km}^{2}$, Doka $2.57 \mathrm{~km}^{2}$, Kakuri $2,52 \mathrm{~km}^{2}$, Ung Rimi $2.36 \mathrm{~km}^{2}$ and Kudenda $2.34 \mathrm{~km}^{2}$ respectively. Encroachment is observed in the CBD (Doka) and its immediate Communities more and also the industrial layouts of Kakuri and Kudenda than in other communities to show the impact of attractiveness of investment towards the center. The implication of this pattern of encroachment involving major investments centers is high flood risk and damage potential in the event of flood.

Figures $2 \mathrm{~b}, \mathrm{c}, \mathrm{d}$, e and $\mathrm{f}$ are maps representing floodplain encroachment by various communities for the periods of 1967, 1987, 1995, 2001, and 2006 respectively.

The trend in floodplain encroachment are graphically represented in Figures $3 \mathrm{a}$ and $3 \mathrm{~b}$ based on regression analysis using suitable models. The regression analysis all reveal increasing trends in floodplain encroachment. The rates of these encroachment however, show temporal variations as shown in Table 2, therefore predictions may not be precise.

\section{Conclusion and Recommendation}

This study has shown that floodplain encroachment has progressed at an unprecedented rate in Kaduna metropolis in the face of increasing urban flooding episodes following climate change responses and poor land use practices, especially in tropical developing cities and Nigeria in particular where ENSO events have been reported to also account for rainfall variability (Shamshudin, 1993; Sawa, 2002; Ati, 2006). Kaduna Metropolis has experienced rapid urban growth, which has extended into the river Kaduna floodplain. The floodplain encroachment is particularly highest in the major centers of high socio-economic investments in the proximity of the CBD. This pattern of encroachment predicts high risk of severe socio-economic losses in the event of flood episodes. This floodplain encroachment in the urban segment of the river increases flood risk at the downstream communities and the shiroro dam as already observed and reported (Halilu, 2003; Bell, et al., 2003; Tadaferua, 2003). 
Recommendations include proactive measures to stop further development on the remaining $47.17 \%$ of unencroached part of the floodplain. This could be achieved through buyouts policy by buying property or vacant land located in flood hazard prone areas by government to prevent future development, flood compensation banking, floodplain zoning undeveloped land can be utilized for recreation, essential transport and utilities infrastructure and conservation landuses which have less damage potentials in the events of floods, especially when supported with warning and evacuation facilities. Development policies on floodplain should be merit-based and formulated in consultation with community, and private developers. The need to implement Kaduna Metropolis Floodplain Action Group to regulate floodplain ordinances and acquiring and storing relevant data through an equipped Watershed Information System.

\section{References}

Abashiya, M. (2006). Influence of Man-Made Structures on Floods in the Northern Parts of Kaduna Metropololis Nigeria. Unpublished M.Sc Thesis Department of Geography, A.B.U Zaria.

Ati, O. F. (2006). Rainfall Characteristics in Drought Prone Sudano-Sahelian Zone of Nigeria: Unpublished Ph.D Thesis, Department of Geography Ahmadu Bello University, Zaria.

Bell, M., Giami A., Grover, E., et al. (2003). Climate Digest. The International Research Institute for Climate and Society Report, October 2003. www.relief.int/w/rwb.nsf

Beyer, J. L. (1974). Global Summary of Human Response to Natural Hazards Floods In: White, G.F. (ed) Natural Hazards Local, National and Global. New York: Oxford University Press, P. 1-65.

Burton, I., Kates, R. W., \& White, G. F. (1978). The Environment as Hazard. New York: Oxford University Press. PP 1-25.

Chapman, J. B., \& Canaan, W. D. (2001). Flood Maps are Key to Better Flood Damage Control: CE NEWS, March 2001, 58-60.

Correia, F. N., Saraiva, M. G., DaSilva, F. N., et al. (1999). Floodplain Management in Urban Developing Areas. Part II GIS-Based Floodplain Analysis and Urban Growth modeling. Water Recourses Management, 13, 23-27. http://dx.doi.org/10.1023/A:1008045419517

Dodson, R. D. \& Li, X. (1999). The Accuracy and Efficiency of GIS-based Floodplain Determinations. Proceedings of the 1999 User Conference, Sandiego, ESRI

Folonusho, S. O. (2004). An Examination of Some Stream Flow Characteristics of River Kaduna at Kaduna South Gauging Station, Kaduna State, Nigeria. Unpublished M.Sc Thesis, Geography Department ABU, Zaria.

Garba, A. (2003). Kaduna Flood: What is at Stake? It could happen again, unless...." Weekly Trust 2003 September $13^{\text {th }}-19^{\text {th }}$, P. $14-15$.

George, W. (2006). Community Involvement in Flood and Floodplain management: the Australian Scene. [Online] Available: http: //www.unescap.esd/water/disaster/australia.htm

Gilbert, O. L. (1991). The Ecology of Urban Habitat. London: New Edition Chapman and Hall. http://dx.doi.org/10.1007/978-94-011-3068-4

Halilu, A. S. (2003). The Use of Nigeria Sat 1 in the Mapping of Flood Hazard Risk along Kaduna River and Shiroro Dam in Kaduna/ Niger States. www.nasrda.org/halilu.pdf

Jaenig, K. C. (2006). St Louis is the Epicenter of Floodplain Encroachments.

Mallo, I. I. Y. (1997). Some Responses of Geomorphic Processes to Urbanization in Barnawa River Catchments, Kaduna Metropolis. Northern Nigeria. Unpublished M.Sc Thesis, Geography Department ABU, Zaria.

Sawa, B. A. (2002). Persistance of Wet and Dry Spells North of Lat. $10^{\circ}$ in Nigeria. Unpublished M.Sc Thesis, Geography Department ABU, Zaria

Shamshi, U. M. (2006). GIS Application in Floodplain Management [Online] Available: http://www.GIS Application.com (October 28, 2006)

Shamshudin, S. D. (1993). Rainfall in Dakar City an Aspects of its Drainage System Development; A Historical Perspective. Reports on Tropical Urban Climate $28^{\text {th }}$ march to $2^{\text {nd }}$ April, 1993 in Dhaka, Bangledesh pp97-102.

Tadaferua, U. (2003). Panos/ Global Knowledge Partnership Reporting on the Information Society Awards. www.panos.uk. 
Table 1. Summary of Results and Analysis of Kaduna urban Growth and floodplain Encroachment

\begin{tabular}{|l|l|l|l|l|l|l|}
\hline Year & $\begin{array}{l}\text { Built-up } \\
\text { Extent } \\
\left(\mathrm{Km}^{2}\right)\end{array}$ & $\begin{array}{l}\text { Total } \\
\text { Floodplain } \\
\text { Area }\left(\mathrm{Km}^{2}\right)\end{array}$ & $\begin{array}{l}\text { Extent of Built-up } \\
\text { Encroachment on } \\
\text { Floodplain }\left(\mathrm{Km}^{2}\right)\end{array}$ & $\begin{array}{l}\text { Extent of un } \\
\text { encroached } \\
\text { Floodplain }\left(\mathrm{Km}^{2}\right)\end{array}$ & $\begin{array}{l}\% \text { of Un } \\
\text { Encroached } \\
\text { Floodplain }\end{array}$ & $\begin{array}{l}\text { encroached } \\
\text { Floodplain }\end{array}$ \\
\hline 1967 & 21.10 & 48.55 & 2.02 & 46.53 & 4.16 & 95.84 \\
\hline 1987 & 126.13 &, & 15.20 & 33.35 & 31.31 & 68.69 \\
\hline 1995 & 158.96 &, & 18.25 & 30.30 & 37.59 & 62.41 \\
\hline 2001 & 172.47 &, & 22.19 & 26.36 & 45.70 & 54.30 \\
\hline 2009 & 181.01 &, & 25.65 & 22.90 & 52.83 & 47.17 \\
\hline
\end{tabular}

Table 2. Summary Results of floodplain Encroachment by Communities in Kaduna Metropolis (1967-2009)

\begin{tabular}{|l|l|l|l|l|l|l|l|}
\hline S/No & Communities & \multicolumn{4}{|l|}{ Extent of Encroachment $\left(\mathrm{km}^{2}\right)$} & ${\text { Encroachment change } \mathrm{km}^{2}}^{2}$ \\
\hline & & 1967 & 1987 & 1995 & 2001 & 2009 & $1967-2009$ \\
\hline 1 & Barnawa & 0.24 & 1.948 & 2.13 & 2.13 & 2.39 & 2.15 \\
\hline 2 & Kakuri & 0.20 & 1.60 & 2.05 & 2.05 & 2.52 & 2.32 \\
\hline 3 & Ung. Muazu & 0.01 & 1.42 & 1.42 & 1.70 & 2.91 & 2.90 \\
\hline 4 & Kabala Doki & 0.14 & 1.43 & 1.72 & 1.81 & 1.84 & 1.70 \\
\hline 5 & Narayi H/Cost & 0.00 & 0.01 & 0.01 & 0.61 & 0.01 & 0.01 \\
\hline 6 & Nasarawa & 0.00 & 1.19 & 1.20 & 1.20 & 1.20 & 1.20 \\
\hline 7 & Kudenda & 0.00 & 0.20 & 0.22 & 1.98 & 2.34 & 2.34 \\
\hline 8 & Narayi & 0.00 & 0.30 & 0.31 & 0.78 & 0.78 & 0.78 \\
\hline 9 & Tudun Wada & 0.31 & 2.54 & 3.18 & 3.18 & 3.74 & 3.43 \\
\hline 10 & Ung. Rimi & 0.30 & 1.83 & 1.93 & 2.35 & 3.36 & 2.06 \\
\hline 11 & Doka & 0.82 & 1.96 & 2.54 & 2.54 & 2.57 & 1.75 \\
\hline 12 & Badiko & 0.00 & 0.26 & 0.31 & 0,32 & 0.39 & 0.39 \\
\hline 13 & Rigasa & 0.00 & 0.52 & 0.52 & 1.25 & 1.44 & 1.44 \\
\hline 14 & Malali & 0.00 & 0.38 & 0.60 & 0.62 & 0.84 & 0.84 \\
\hline 15 & Badarawa & 0.00 & 0.00 & 0.00 & 0.00 & 0.10 & 0.10 \\
\hline 16 & Kawo & 0.00 & 0.07 & 0.08 & 0.17 & 0.21 & 0.21 \\
\hline 17 & Ung. Dosa & 0.00 & 0.01 & 0.03 & 0.10 & 0.10 & 0.10 \\
\hline & Total & 2.02 & 15.20 & 18.25 & 22.19 & 25.65 & 23.72 \\
\hline
\end{tabular}




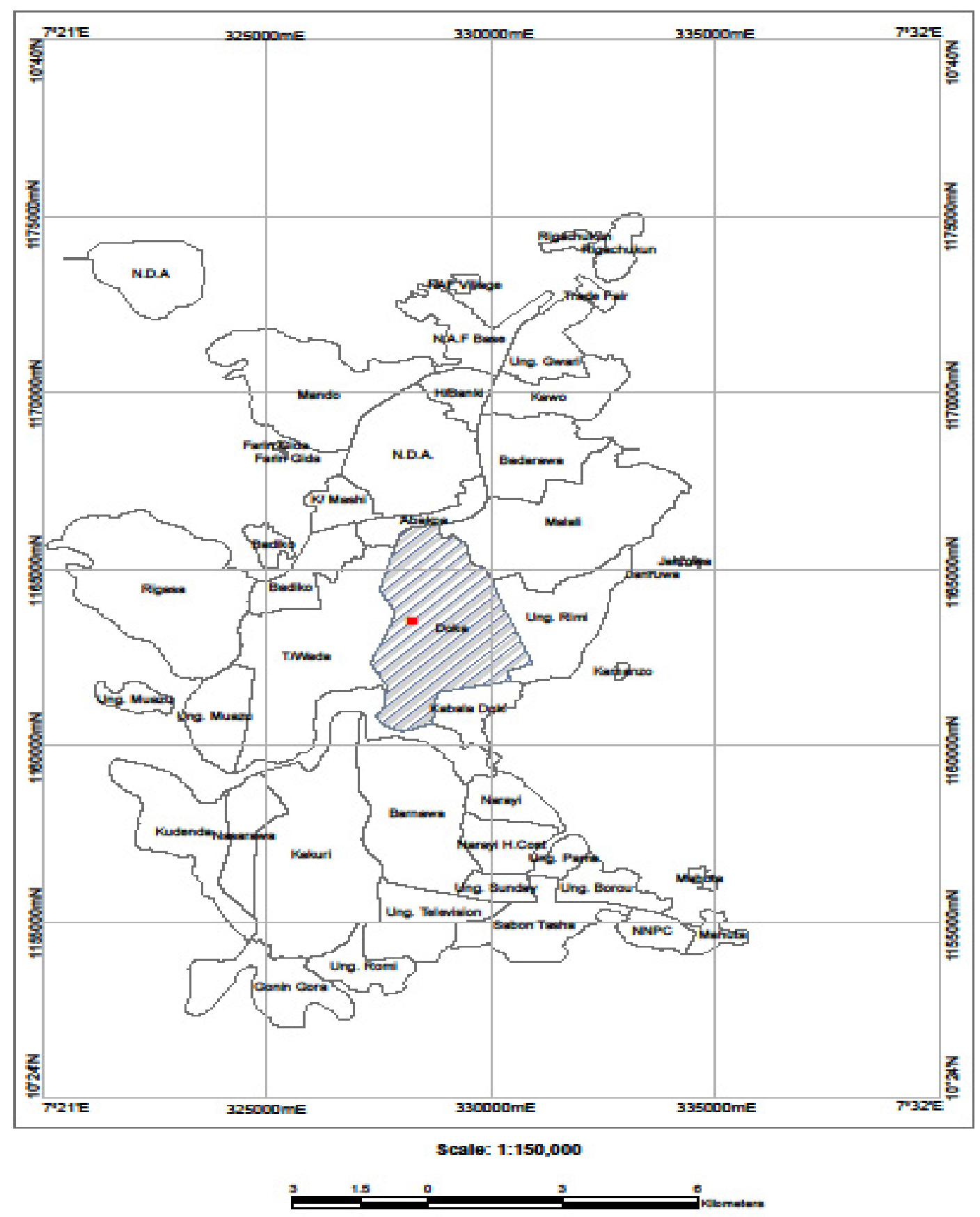

\section{LEGEND}

- Central Business District

Figure 1. Fragmented Sub-centers of Kaduna Metropolitan Built-up 


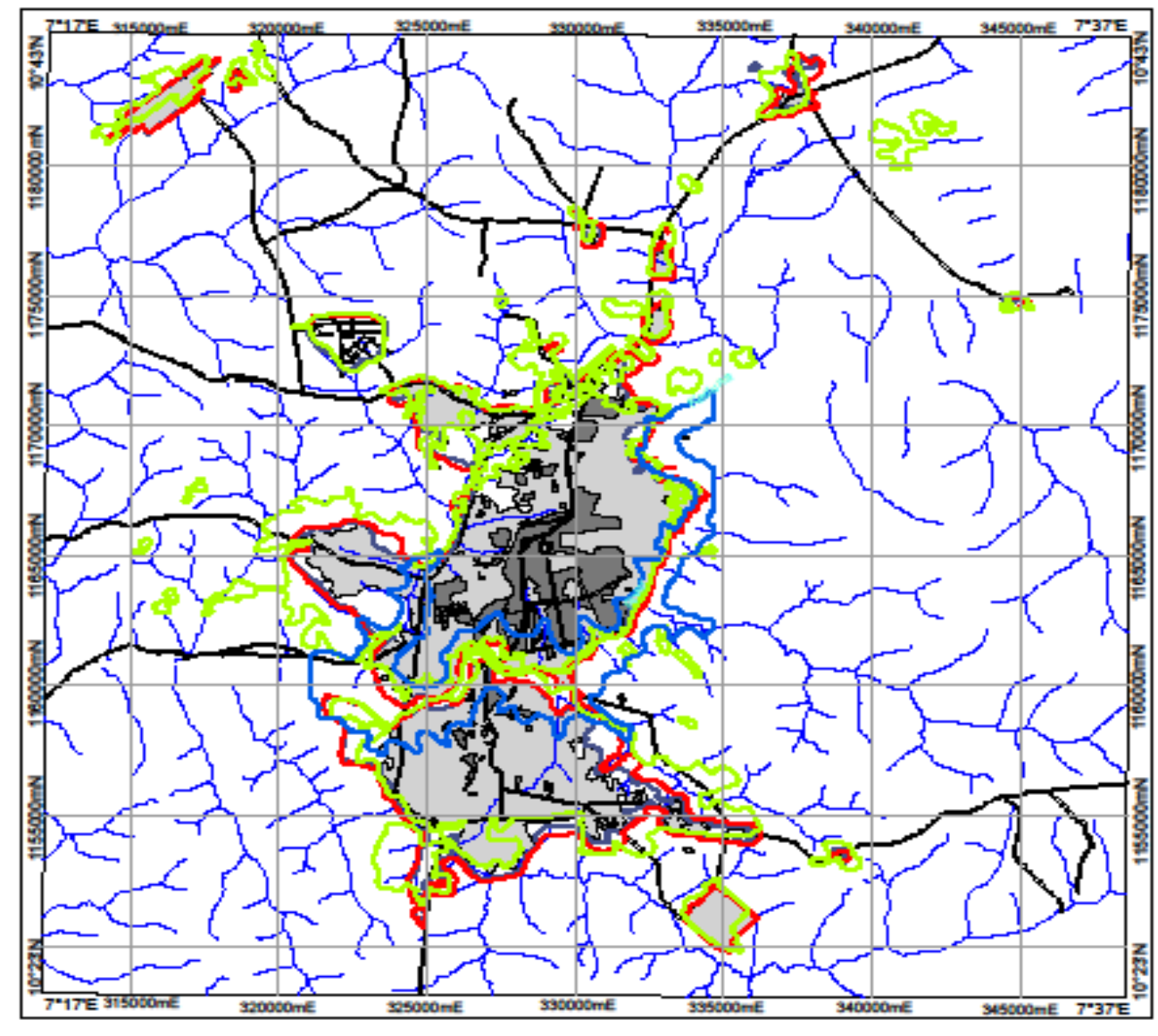

Scale: 1 : 250000

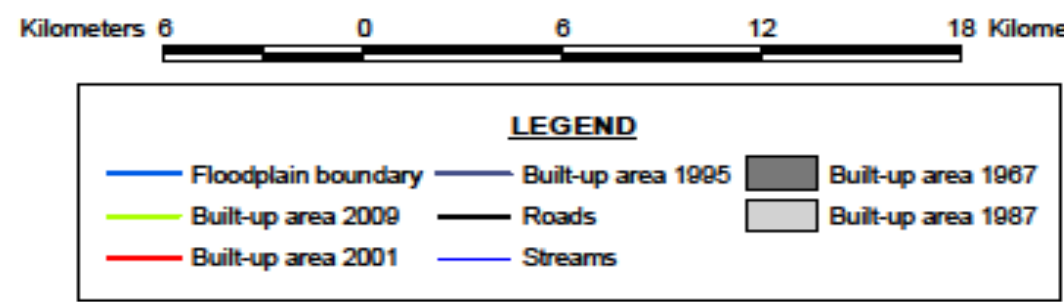

Figure 2a. Composite of Kaduna Urban Built-up Encroachment on Floodplain 


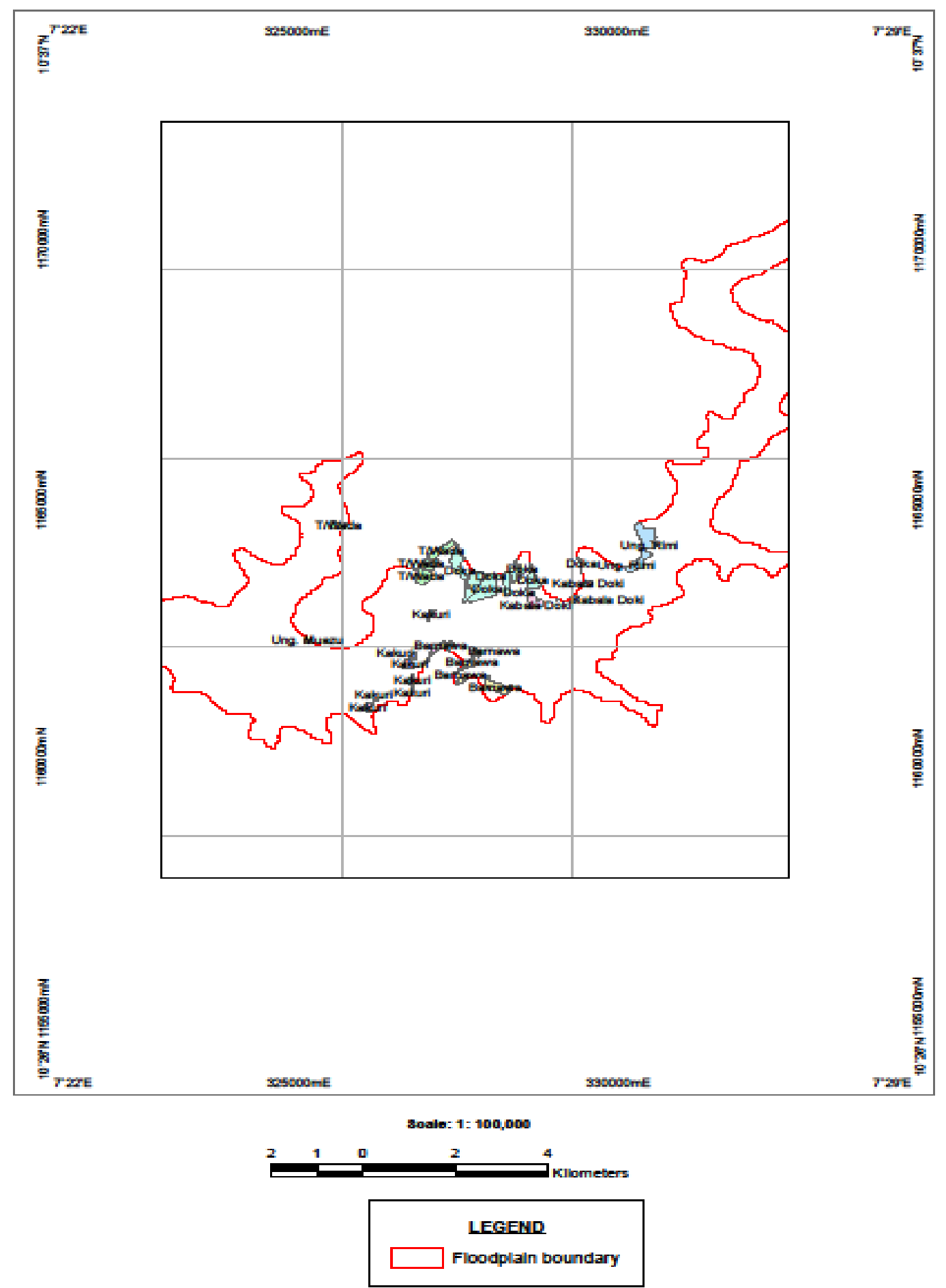

Figure 2b. Built-up Encroachment by Communities on River Kaduna Floodplain (1967) 


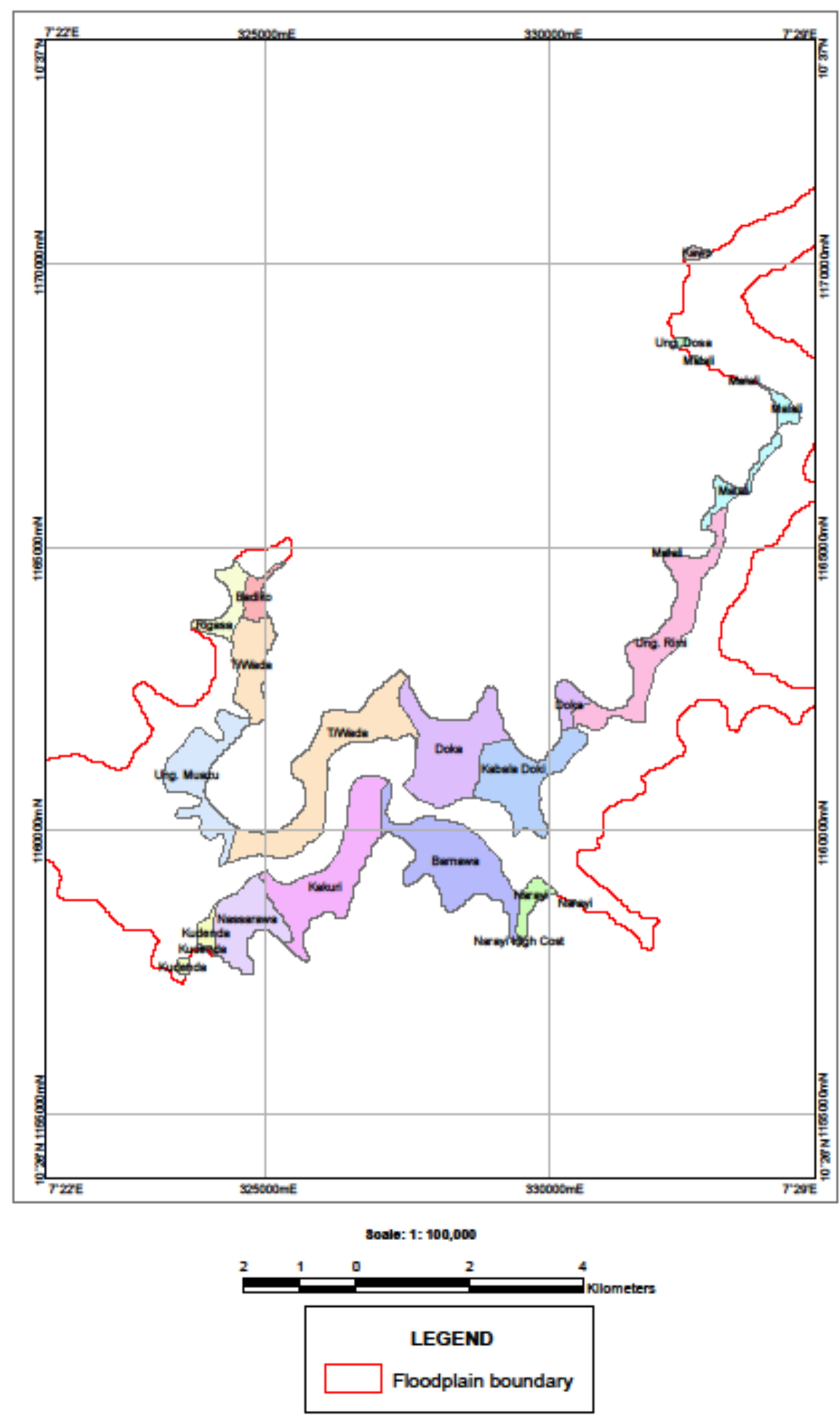

Figure 2c. Built-up Encroachment by Communities on River Kaduna Floodplain (1987) 


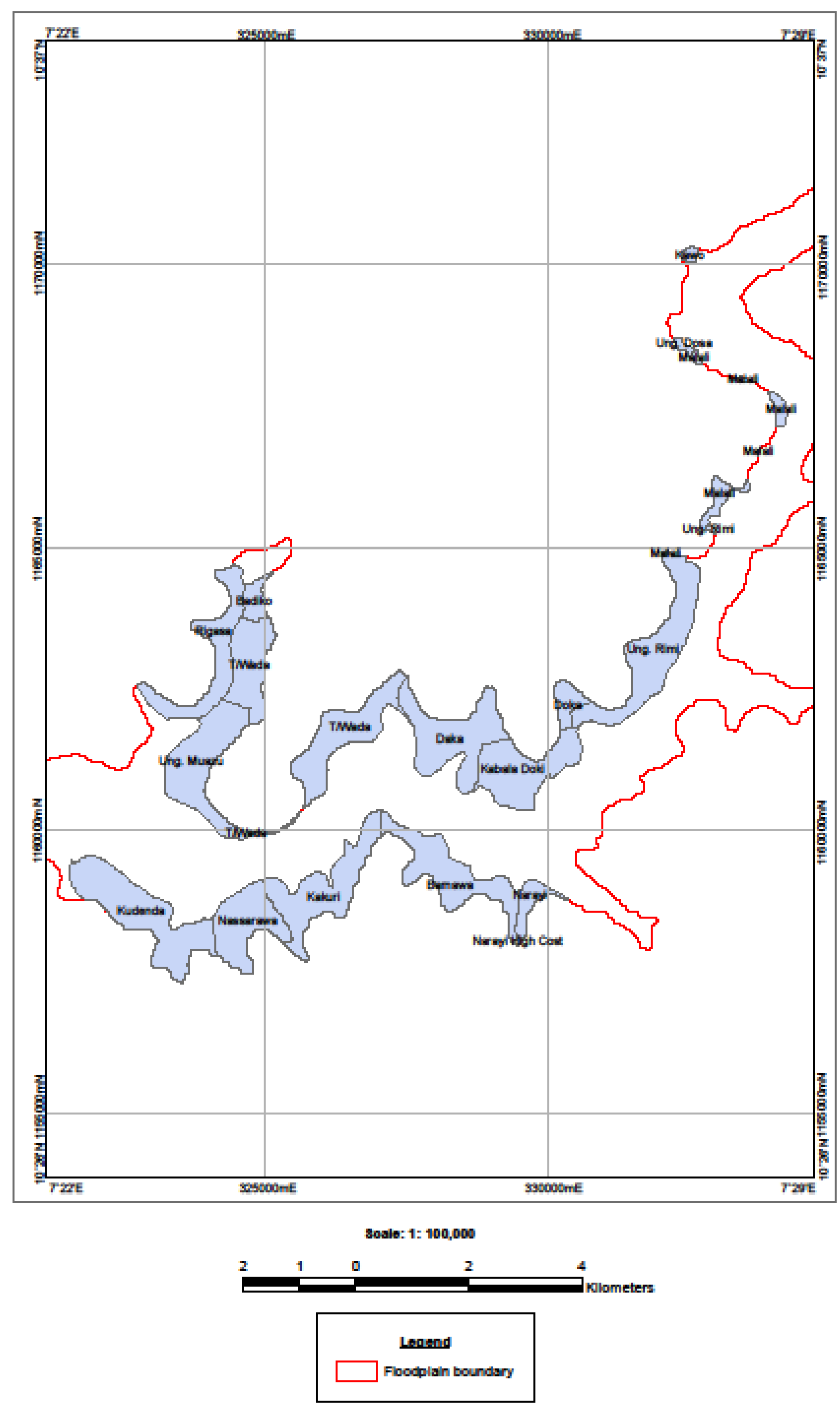

Figure 2d. Built-up Encroachment by Communities on River Kaduna Floodplain (1995) 


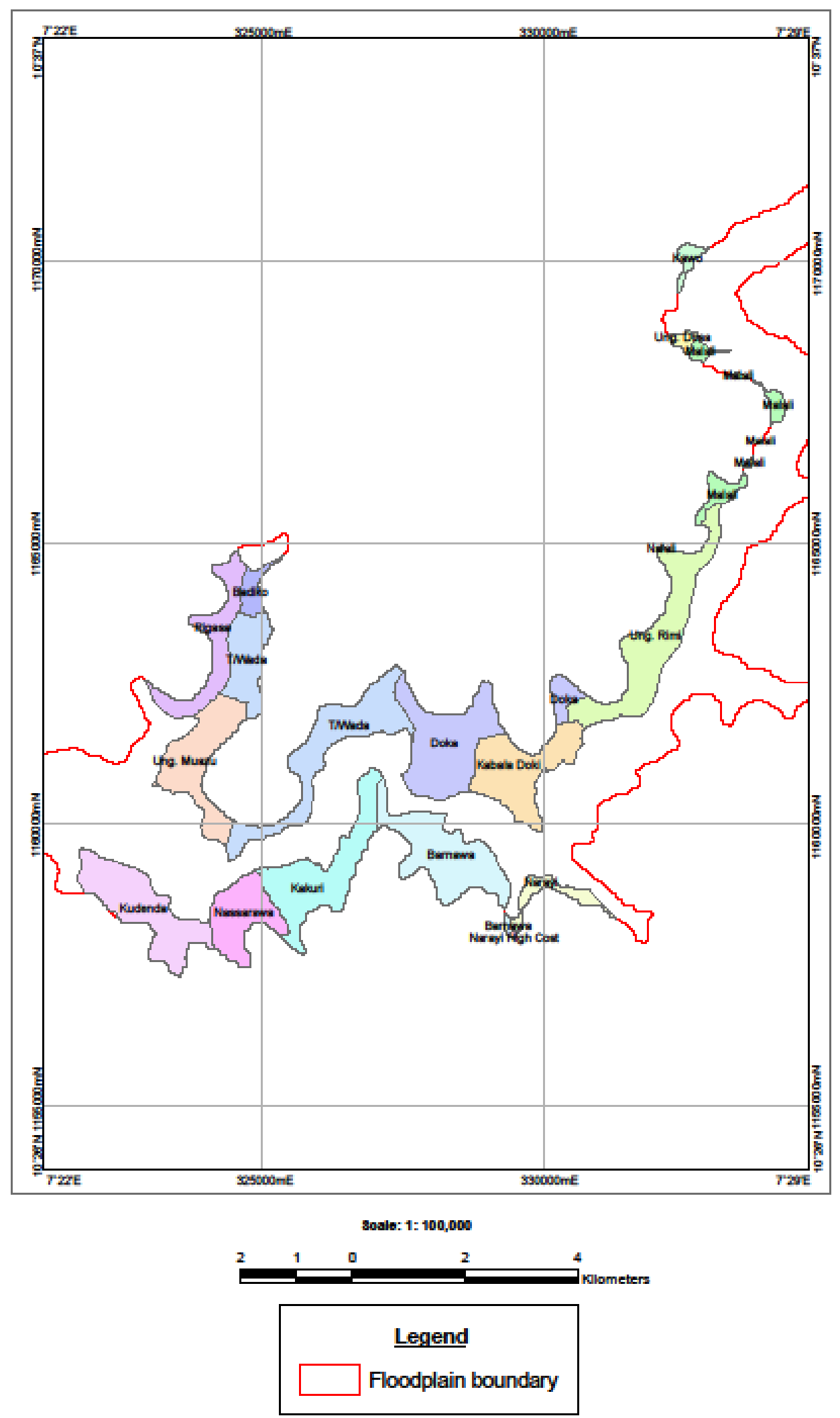

Figure 2e. Built-up Encroachment by Communities on River Kaduna Floodplain (2001) 


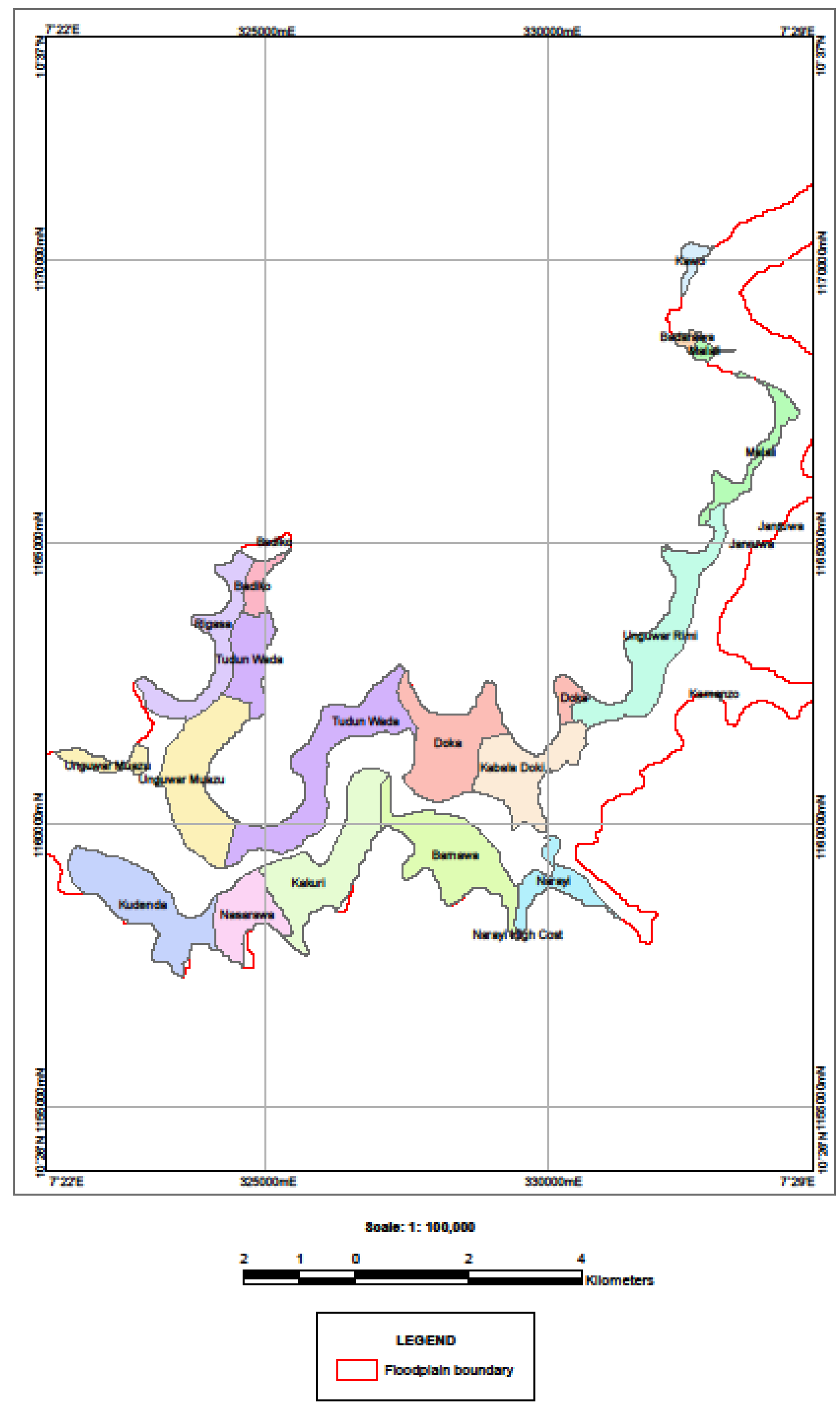

Figure 2f. Built-up Encroachment by Communities on River Kaduna Floodplain (2006) 


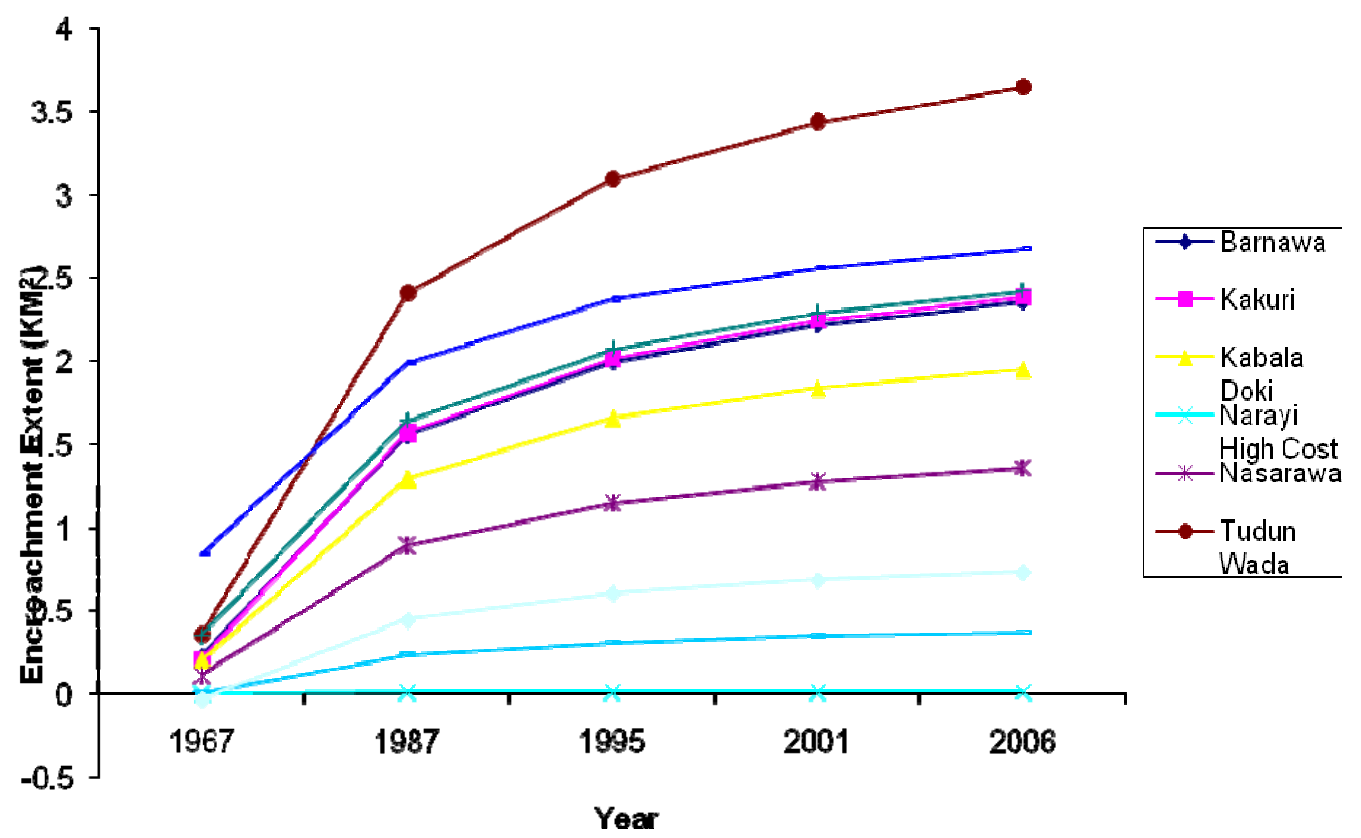

Figure 3a. Flodplain Encroachment by Communities in Kaduna Metropolis (Linear Regression Model)

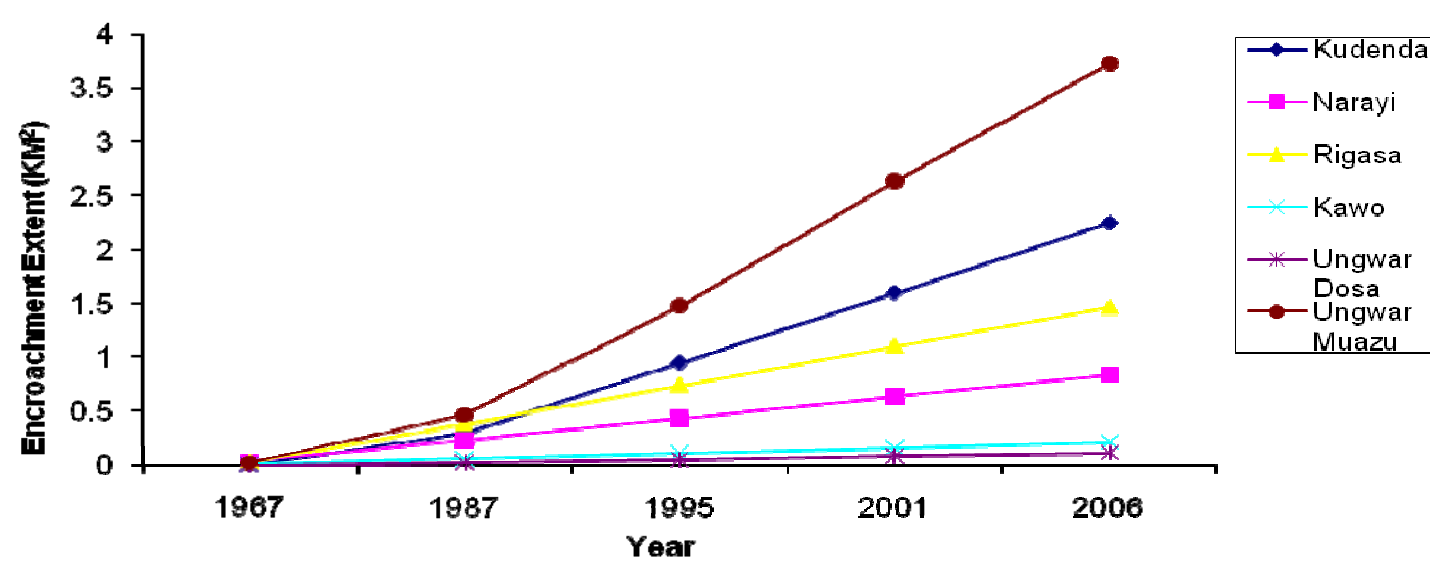

Figure 3b. Floodplain Encroachment by Communities in Kaduna Metropolis (Linear Regression Model) 